\title{
Equine Osteochondrosis: a challenging enigma
}

\author{
P. René van Weeren \\ Department of Equine Sciences, Faculty of Veterinary Medicine, Utrecht University, The Netherlands
}

\begin{abstract}
Summary
Osteochondrosis $(\mathrm{OC})$ is by far the most important equine developmental orthopaedic disease. Depending on the breed, the incidence may be as high as $25 \%$ and losses to the equine industry in economical terms and in terms of welfare are considerable. Osteochondrosis is a multi-factorial disorder in which both hereditary components and management aspects play key roles. Important management factors include nutrition and biomechanical loading of the joints. The concept of the disease has changed considerably over the past years and the condition is now seen as a dynamic process in which lesions may appear and disappear again (be repaired). The last possibility exists as long as the metabolic level of the extracellular matrix of the articular is still high enough to permit such repair. Current research focuses primarily on the molecular mechanisms leading to osteochondrosis and on the genetic background. The complex, multi-factorial character of clinical $O C$, that can be seen as the outcome of two different processes (pathogenesis and repair), and preliminary results pointing at the involvement of different gene sets for different joints, make it improbable that reliable, simple and decisive genetic tests will soon come onto the market.
\end{abstract}

Keywords: horse, osteochondrosis, OCD, OC, developmental orthopaedic disease, cartilage

\section{Osteochondrose des Pferdes - Rätsel und Herausforderung}

Osteochondrose $(\mathrm{OC})$ ist bei weitem die wichtigste orthopädische Entwicklungsstörung des jungen Pferdes. In gewissen Rassen kann die Inzidenz bis 25\% betragen und OC beeinträchtigt deshalb den ganzen Pferdensektor in schwerem Maße. Osteochondrosis ist eine multifaktorielle Krankheit wobei genetische sowie Umgebungsfaktoren eine Rolle spielen. Wichtige Umgebungsfaktoren sind unter anderen die Ernährung und biomechanische Einflüsse. Das Konzept der Osteochondrose hat sich in den vergangenen Jahren ziemlich verändert. Heute sieht man $\mathrm{OC}$ als einen sehr dynamischen Prozess in dessen Verlauf Läsionen entstehen aber auch wieder verschwinden (repariert werden). Die Reparatur kann jedoch nur stattfinden wenn der Metabolismus der extrazellulären Matrix des Gelenkknorpels noch groß genug ist, was bedeutet dass dies nur bei sehr jungen Tieren geschehen kann. Die aktuelle Osteochondrose-Forschung richtet sich vornehmlich auf die molekulären Mechanismen der Krankheit und auf deren genetischen Hintergrund. Die sehr komplizierte Natur von Osteochondrose, die Tatsache, dass die klinische Manifestation das Ergebnis zwei unterschiedener Prozesse ist (Entwicklung der Läsion und der Reparaturprozess), und preliminäre Ergebnisse der molekulärgenetischen Forschung, die auf die Beteiligung mehrerer und verschiedener Gene für unterschiedliche Gelenke hindeuten, machen es nicht wahrsheinlich, dass bald ein zuverlässiger und eindeutiger Gentest für OC entwikkelt werden kann.

Schlüsselwörter: Osteochondrose, OCD, OC, Knorpel, Entwicklungsstörung, Orthopädie

\section{Introduction}

In the equine literature both the terms "osteochondrosis" (OC) and "osteochondritis dissecans" (OCD) are commonly used. The term "osteochondritis dissecans" is the original term, which was coined by König in 1887 and used to describe loose or semi-loose bodies in joints of young persons that could have three causes: 1) very severe trauma, 2) lesser trauma and necrosis, and 3) minimal trauma exciting an underlying lesion (König 1887). It is the last, and most difficult, of König's categories that is equivalent to what is commonly meant by the term osteochondrosis $(\mathrm{OC}$ ) in the (equine) veterinary literature, where osteochondrosis is seen as a disturbance of the process of endochondral ossification of incomplete understood aetiology. This disturbance may eventually lead to the formation of semi-loose or even completely loose fragments within a joint, and the condition is then commonly indicated by König's original term of osteochondritis dissecans.
Osteochondrosis (OC) is common in many breeds of horses. In Swedish Standardbreds incidences ranged from 10.5\% to 26\% (Hoppe and Philipsson 1985, Schougaard et al. 1990, Sandgren et al. 1993). In the Warmblood, early Swedish data mention 15\% (Hoppe and Philipsson 1985), more recent figures in the Dutch Warmblood population are higher (25\% in the tarsocrural joint, $15 \%$ in the femoropatellar joint) (Dik et al. 1999). In a large study in 1180 horses in France (mainly Selle Français and Anglo-Arabs, a minority of Thoroughbreds) an incidence of $13.3 \%$ was reported in the tarsocrural joint (Denoix and Valette 2001). A recent large-scale field study in Germany in several Warmblood breeds yielded figures of $19.5 \%$ for the metacarpophalangeal joints, $11.1 \%$ for the tarsocrural joint and 7.2\% for the femoropatellar joint (Arnan and Hertsch 2004). Overall, it has been estimated that in North-Western Europe alone annually 20.000 - 25.000 foals are born that will develop some degree of OC (van Weeren 
and Barneveld 1999a). Osteochondrosis is a decisively invalidating disease only in relatively exceptional cases where lesions are so extensive that no repair is possible. Nevertheless, the ailment has a strong impact on the economics of the equine industry, and to a certain extent on animal welfare, as tens of thousands of animals are operated upon each year. Apart from the direct economical loss, there is an even larger indirect cost of the disease, as many studbooks will not approve horses with evidence of $\mathrm{OC}$, which implies the exclusion of a large part of the gene pool. A last, but not insignificant, economic impact of $\mathrm{OC}$ is the loss in value of animals showing radiographic evidence of OC, regardless of their athletic capacities. These factors make $\mathrm{OC}$ into one of the major orthopaedic diseases in the horse, and by far the most important developmental orthopaedic disorder. It is also one of the most heavily discussed disorders with an almost somewhat mystic aura, as there are still many uncertainties with respect to the true nature of the disease and the aetiological factors involved.

In this article first a very brief update on the process of endochondral ossification is given, followed by an overview of the concept of $\mathrm{OC}$ and how this has changed during the past decades until the current concept that fits $O C$ in the overall picture of articular (cartilage) development in the growing animal. The gross pathogenesis and the many proposed aetiological factors are then discussed and the paper ends with a note on current research directions and which developments might be expected in the near future.

\section{The process of endochondral ossification}

In all mammals the primordial skeleton is laid down as a cartilaginous structure that, during growth and development of the animal, is modelled in a coupled process of simultaneous growth and transformation into bone. Unlike the situation in mature articular cartilage, all these foetal cartilaginous structures are well vascularised by vessels running through so-called cartilage canals. Ossification of the primary centres of ossification in the diaphyses of the long bones starts early in foetal life and at the time of birth all these diaphyses are bony structures. This does not apply to many secondary centres of ossification in the epiphyses of the long bones, which are still partly cartilaginous at the time of birth. After birth, longitudinal growth of long bones results from the growth plates or physes where, from a germinal layer of cells that are called resting cells, proliferation of chondrocytes starts that lay down a scaffold of extracellular matrix, then the cells hypertrophy and later go into apoptosis. The scaffold is used for the apposition of primary bone by osteoblasts originating from the metaphysis. In the epiphyses of the long bones a similar process takes place, but is not as far developed as in the diaphyses at birth, albeit large differences in time frames exist between joints. In some cases there is still a complete ring of cartilage around the ossification centre, connecting articular cartilage with the growth plate. During development ossification takes place first at the border with the physis and at the perimeter of the epiphysis, resulting in a situation similar to the one in the diaphysis. The thick cartilage mass at the articular side now functions as a kind of growth plate where the simultaneous processes of growth, remodelling and ossification take place that finally will result in the considerably thin- ner layer of articular cartilage in the mature animal. It is at this level that the characteristic lesions of equine osteochondrosis (Fig. 1 = hock with lesion) are seen. During the process of endochondral ossification and thinning of the articular cartilage layer, the vascularisation of the cartilage ceases to exist and the cartilage canals disappear. In the horse it has been shown that the last canals disappear at approximately 7 months (Carlson et al. 1995).

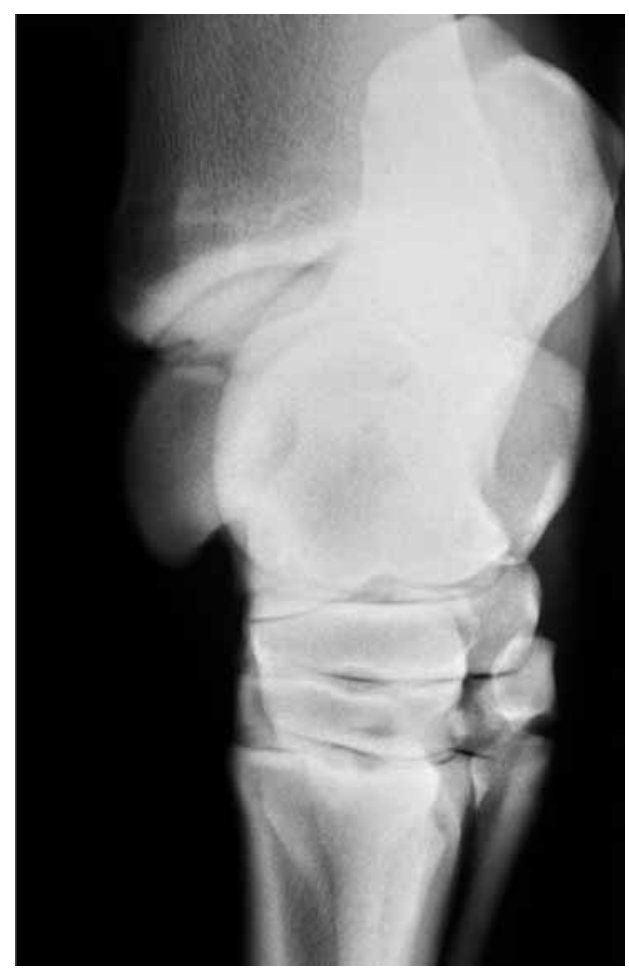

Fig 1 Classic osteochondrotic lesion located at the distal intermediate ridge of the tibia.

Klassische osteochondrotische Läsion an der distalen Tibia

\section{Osteochondrosis: gradual development of a concept}

It was in 1947 that Nilsson gave the first description of what is retrospectively judged to have been OC. However, the real history of $\mathrm{OC}$ does not start before the publication of Birkeland and Haakenstad in 1968, who described a series of 7 cases of $\mathrm{OC}$ of the distal ridge of the tibia, but did not use the term osteochondrosis yet. In the early 1970s gradually more publications appeared, and in the mid-seventies Olsson and Reiland with other Scandinavian co-workers published a comprehensive study on osteochondrosis in a multitude of species $10 /$ sson and Reiland 1978, Reiland 1978, Reiland et al. 1978, Rejnö and Strömberg 1978, Strömberg and Rejnö 1978).

Osteochondrosis was originally seen as a largely static condition from which the animal did or did not suffer, but this concept started gradually to change. Strömberg (1979) already reported changes in radiographic appearance of femoropatellar $O C$ after repeated examinations. Dabareiner et al. (1993) stated after sequentially radiographing a number of foals that osteochondrotic lesions of the distal femur could progress until the age of 9 months and Carlsten et al.(1993) found that no major osteochondrotic lesions in the tarsocrural joint originated after 8 months. Interestingly, they also noted a regression before the age of 8 months of a number 
of minor lesions, which had been detected first between ages 1 and 3 months. Dik et al. (1999) radiographed the tarsocrural and femoropatellar joints of 43 foals on a monthly basis from the age of 1 month until age 5 months and of 19 of them until age 11 months. The study showed that not only minor lesions, but also radiographically visible fragments could disappear without leaving any trace. The ages at which lesions originated, and until which they tended to disappear,

\section{Intermediate ridge distal tibia}

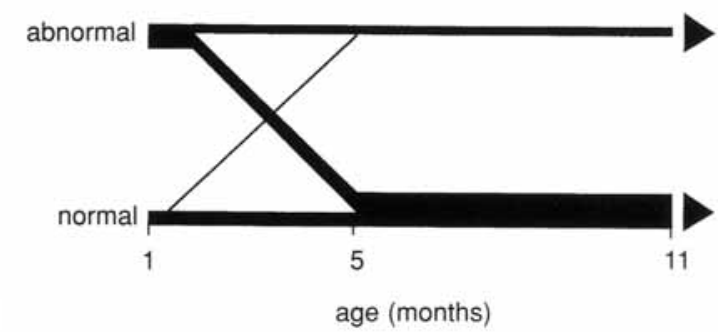

\section{Midregion lateral ridge femoral trochlea}

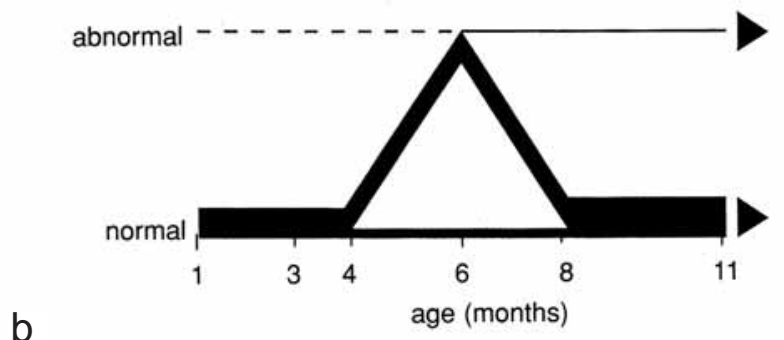

Fig $2 a$ Schematic diagram of development of $O C$ lesions at the intermediate ridge of the distal tibia. Lesions are present at very early age, but disappear for the major part before the age of 5 months. After this age the situation remains stable. b) Schematic diagram of the development of OC lesions at the mid-region of the femoral trochlea. Lesions develop later. Most of them disappear as well, but this happens later too (at approximately 8 months).

a) Schema der Entwicklung von OC-Läsionen an der distalen Tibia. Läsionen sind sehr früh bereits sichtbar, verschwinden jedoch bei den meisten Tieren vor dem Alter von 5 Monaten. Nach diesem Zeitpunkt bleibt die Situation stabil. b) Schema der Entwicklung von OC-Läsionen im medialen Bereich des Femurrollkamms. Die Läsionen entstehen hier später. Die meisten verschwinden wieder, aber am Femur auch später (ungefähr bis zum Alter von 8 Monaten).

were variable per joint. In the tibiotarsal joint lesions at the intermediate ridge of the distal tibia and at the distal aspect of the lateral trochlear ridge of the talus were seen already within the first few months of life, but disappeared for the major part before age 5 months. In the femoropatellar joint lesions originated later and peaked at approximately 6 months before declining in number until about 8 months after which the situation remained stable (Fig. 2a,b). In a follow-up study in another group of Warmblood foals that was followed for 24 months, this general joint-specific pattern was confirmed (Enzerink et al. 2000). In that study, very little change in radiographic appearance was noted from 12-24 months. All these observations have led to the conclusion that $\mathrm{OC}$ is by no means a static condition, but in contrast an extremely dynamic one in which lesions appear and disappear during the first months of life. Apparently the time frame for this acti- vity differs between joints (Barneveld and van Weeren 1999). The acknowledgement of the dynamic character of OC has led to a profound change in the concept of the disease. The osteochondrotic lesion, as encountered in the two- or threeyear-old should not be considered the result of a single, simple or complex, pathologic event, but represents the end product of the effect of that event and an ensuing repair process. The latter process has in this case not been entirely success-

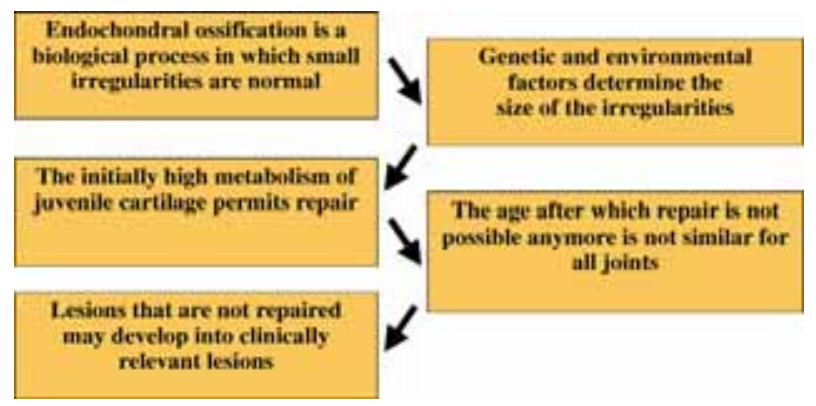

Fig 3 Flow chart presenting the putative pathway along which lesions originating at foal age may eventually develop into clinically manifest lesions in the mature animal.

Flussdiagramm über die möglichen Wege über welche OCLäsionen aus dem Fohlenalter zu klinisch manifesten Läsionen beim erwachsenen Tier führen.

ful in this particular lesion, but has almost certainly been successful in a number of other lesions that were detectable at foal age, but have disappeared since. It is well known that the extracellular matrix of the articular cartilage goes through a phase of rapid remodelling in the neonatal animal. It is in this period that within the joint the topographic heterogeneity in biochemical composition, that is necessary to withstand the locally different biomechanical challenges, develops through the so-called process of functional adaptation (Brama et al. $2002,2004)$. In this process the collagen network of the articular cartilage is moulded under biomechanical influences in a process not unlike that in bone (Wolff 1892). However, whereas bone retains its capacity to remodel throughout the life of the individual, cartilage metabolism decreases quickly in the early juvenile period, leading to very long turnover times in mature individuals (Maroudas 1980, Verziil et al. 2000). The latter fact precludes any substantial remodelling or repair and makes the formation of the collagen network in the early juvenile phase into a once-in-a-lifetime process that may have very important consequences for disease prevention in future life (Helminen et al. 2000). The sharp drop in collagen metabolism in the early juvenile period probably determines when the window for repair of lesions closes. Some lesions, either for originating too late or for being too large, will not have enough time for repair and get "trapped". These are the lesions that may eventually become clinically manifest. This means that in $\mathrm{OC}$ a clear discrimination should be made between the pathogenesis triggered by a number of aetiological factors on the one hand, and the repair process on the other (van Weeren and Brama 2003, van Weeren 2004). A flow chart for the putative mechanism of OC based on this concept is given in Fig. 3.

\section{Pathogenesis and aetiological factors}

There is little controversy about the gross pathogenetic mechanism of OC. Disturbances of the process of endo- 
chondral ossification result in irregularities in thickness of the epiphyseal cartilage. These create areas of focal weakness and, through the longer diffusion pathway, affect the nutrition of the deeper layers of the retained cartilage plugs, leading to necrosis. Biomechanical influences, mainly shearing forces, will then lead to the formation of fissures and produce cartilage flaps, or detachment of cartilage and/or fragments of cartilage and subchondral bone.

The real aetiology is more open to debate. Osteochondrosis is a complex disease of which there is no doubt that it is multifactorial in origin. Biomechanical influences, exercise, failures of vascularisation, nutritional imbalances and genetic influences have all been mentioned and have been investigated to a certain extent. Many, if not all of these are interrelated. The major factors will be discussed briefly.

\section{Biomechanical influences}

Biomechanical loading must play a role in the pathogenesis of osteochondrosis as there is hardly any other way to explain the consistency of predilection sites within specific joints. It is probable that the dramatic changes in biomechanical loading that take place after birth are an important trigger factor for the initiation of lesions. In this respect, it is strongly suggestive that an osteochondrotic lesion has been found in a foal as young as 3 days (Rejnö and Strömberg 1978), but never in foetuses. Biomechanical influences are strongly related with other supposed aetiological factors such as exercise and hereditary factors (through the strongly genetically determined conformation of the animal). However, apart from direct blunt trauma that will cause an osteochondral fracture and not $\mathrm{OC}$ in a more strict sense, biomechanical forces are considered a necessary factor rather than a solely acting cause.

\section{Failures of vascularisation}

In the pig extensive studies have been performed on the vascularization of growth cartilage, the physiologic process of regression of cartilage canals, and disturbances thereof as possible causes for OC (Ekman et al. 1990). In that species the most recent work led to the hypothesis that $\mathrm{OC}$ was caused by local biomechanical damage to cartilage canals, especially to the anastomosing branches that run through the ossification front from the bone marrow (Ytrehus 2004, Ytrehus et al. 2004).

In the horse cartilage canals are present, as in any other species, in the juvenile period and it is tempting to extrapolate the pathogenetic mechanism that now seems firmly established in the pig to the horse as well. However, there are several distinct interspecies differences. Focal islands of chondronecrosis as seen in the pig are not frequent findings in the horse. Further, Shingleton et al. (1997) found patent canals in retained areas of viable equine cartilage. This led them to conclude that retaining of cartilage canals may be instrumental for the occurrence of $O C$, not early dysfunction of them. Necrosis of cartilage would be the sequel rather than the primary factor.

\section{Exercise}

Exercise is known to be the steering factor in the process in which at very young age the biochemical composition of the extracellular matrix of articular cartilage takes on a topographically heterogeneous character in the so-called process of functional adaptation (Brama et al. 2000). It might therefore influence the occurrence of $O C$ as well. Thus far, experimental evidence has not been convincing, however (Jeffcott 1991, van Weeren and Barneveld 1999b, Wilke 2003). Exercise may be a factor co-determining the final appearance of osteochondrotic lesions, but does not seem to be of primary pathogenetic importance.

\section{Nutrition, hormonal factors and growth rate}

In relation to $O C$ nutritional factors can be grossly divided into minerals and trace elements, and dietary energy level. The latter factor is closely related to growth rate, a factor heavily incriminated in $O C$ pathogenesis in a large number of species. However, growth rate is not only determined by energy intake, but by genetic predisposition as well.

Interest in trace elements was raised by a report on the relationship of low copper serum and ceruloplasmin levels and osteochondrosis (Bridges et al. 1984) and by epidemiological studies on dietary mineral and trace element levels related to the occurrence of developmental orthopaedic disease (Knight et al. 1985). A theory in which OC would be caused by the effect of copper deficiency on lysyl oxidase, an enzyme implicated in the formation of cross-links between collagen molecules, was born, but was soon challenged by many contradictory experimental data. In a more recent study it was shown that copper had a positive effect on the repair of osteochondrotic lesions, but not on the pathogenesis in a more strict sense (van Weeren et al. 2003).

Dietary energy levels have been implicated in the pathogenesis of OC for decades. Whilst the data about the effect of growth rate is conflicting and the concept of a high growth rate, putting pressure on the process of endochondral ossification and thus leading to irregularities, may be too simplistic, there is substantial evidence for other mechanisms. Excessive levels of energy, especially when fed in the form of easily digestible carbohydrates (Glade 1986, 1987), will result in a strong postprandial hyperinsulinemia. Insulin and the derivatives insulin-like growth factor I and II (IGF-I/II) have a direct effect on the process of endochondral ossification, acting as mitogens for chondrocytes and stimulating chondrocyte survival or suppressing apoptosis. Insulin also stimulates a rapid removal from the circulation of the thyroid hormones T3 and T4, which are involved in the final stages of chondrocyte differentiation and in the metaphyseal invasion of growth cartilage by blood vessels (Jeffcott and Henson 1998). An indication of the importance of carbohydrate levels in the feed comes from a recent study in Kentucky on the influence of the season on the occurrence of OC. Early foals appeared to have a significantly higher incidence of $O C$ in the tarsocrural joints, but late foals had a higher incidence in the femoropatellar joints. This seemingly contradictory effect of the season could be explained by the different windows of vulnerability of these joints, which appeared to coincide with 
the spring and autumn peaks in the energetic value of the grass (Paasch and Bramlage 2004).

There is hardly any doubt that the pathogenetic mechanism outlined above plays a certain role in the development of equine osteochondrosis. However, it is unlikely that it is the sole mechanism as many lesions provoked by the administration of high carbohydrate diets were similar, but not always identical to those seen in clinical OC. Besides, also many lesions were seen in the growth plate (Glade and Belling 1984). In contrast to some other species, in the horse clinical $\mathrm{OC}$ is rarely, if ever, seen in the growth plate.

\section{Genetics}

In the horse $\mathrm{OC}$ lesions are rarely found in ponies and have a much lower incidence in feral horses (Voûte et al. 1997, Valentino et al. 1999) This strongly suggests a considerable genetic influence. Further evidence comes from studies showing large differences in incidence of $\mathrm{OC}$ between progeny groups of different stallions Strömberg and Rejnö 1979, Schougaard et al. 1990). In this context, there is no doubt that $\mathrm{OC}$ is a polygenic trait and that the way of inheritance is complex (Philipsson 1996), making reduction of the incidence by selection procedures difficult. There are various explanations for this. First, there is evidence that different genes may be involved in different joints (Löhring and Distl 2004), which may be related to joint-dependent differences in the timetable of maturation of the extracellular matrix (ECM) and the reaction of this partly immature ECM to loading. Second, the dynamic nature of $\mathrm{OC}$ makes that many animals being radiographically free from lesions at age 3 or 4 years when they enter the stallion selection procedures, will have shown evidence of the disease as a foal and hence are genetically predisposed. Lastly, there is the fact that the clinically or radiographically evident $\mathrm{OC}$ lesion in the mature animal is the result of two different processes with most probably entirely different genetic backgrounds, namely pathogenesis and repair. Recently studies have started that try to identify OC related genes through modern molecular genetic techniques. Although this certainly is a way forward, these studies are all hampered by the fact that they try to link the final phenotype, and thus the end product of various processes, to certain genes. It is highly unlikely that in the near future $\mathrm{OC}$ can be selected against using a simple genetic test.

\section{Current research and future developments}

Most research in recent years on equine osteochondrosis has focused on the molecular mechanisms involved. Both chondrocyte behaviour and composition of the extracellular matrix have been targets. Studies have focused, in normal and osteochondrotic cartilage, on the expression of various collagen types that are represented in the extracellular cartilage matrix (collagens type II, $\mathrm{VI}$ and $\mathrm{X}$ ), and on the expression of growth factors (Transforming Growth Factor-B, IGF-I/II) that are known to play a role in the development and maturation of cartilage (Henson et al. 1997a,b). There were distinct differences in expression patterns between normal and abnormal tissues with notably high levels of activity around the chondrocyte clusters or chondrones that are typically seen in early cases of OC. This increase in activity is in line with the higher level of chondrocyte metabolism as demonstrated by van den Hoogen et al. (1999) and may be the primary, but is more likely a secondary event representing an attempt at repair (Muir 1995).

Gradually evidence has grown that changes in collagen metabolism play an important role in the molecular mechanism of OC. The increased collagen turnover in osteochondrotic cartilage is reflected by an increase in collagen split products that can be detected in the synovial fluid. (Laverty et al. 2002, Billinghurst et al. 2004). Additional evidence for the crucial role of collagen was provided by the demonstration of differences in post-translational modifications of collagen type II in samples from early lesions (van de Lest et al. 2004). The question whether these collagen-related changes represent a secondary or a primary event remains unanswered, however.

An area more likely to be related to the initiation of $\mathrm{OC}$, i.e. to real pathogenesis, is the mechanism that controls the process of endochondral ossification. Cartilage differentiation is partially controlled through parathyroid hormone related peptide (PTH-rp) and Indian Hedgehog (Ihh) and a significant increase of PTH-rp protein and mRNA expression in chondrocytes from $\mathrm{OC}$-affected cartilage has been shown (Semovolos et al. 2002). However, this was not true for Ihh and also the expression of bone morphogenic peptides- 6 and -2 was not changed (Semovolos et al. 2004).

Osteochondrosis is to a certain extent still an enigma to the veterinary profession. Using modern molecular biological and genetic techniques, researchers are closing in on various aspects of the disease. The fact that osteochondrosis is a relatively "new disease" with a very low incidence in feral horses (Valentino et al. 1999) strongly implicates modern breeding policies and management aspects as key factors in this disease. However, "simple and straightforward solutions" cannot be expected if one realises that $\mathrm{OC}$ is a multifactorial disease in which the problem is not to single out a specific causative factor, but to determine to what extent, and in which order, a variety of factors play a role. To speak with Albert Einstein: "One should make difficult things as simple as possible,...but not simpler".

\section{Literature}

Arnan P. und Hertsch B. (2004): Röntgenologische Untersuchung zur Erfassung der Osteochondrosis dissecans im Fessel-, Sprung- und Kniegelenk im Vergleich vom Fohlen zum Zweijährigen. In: Proc. Göttinger Pferdetage '04, Göttingen, 2004, Institut für Tierzucht und Haustiergenetik Georg-August-Universität, 1 15-124

Barneveld A. und van Weeren P. R. (1999): Conclusions regarding the influence of exercise on the development of the equine musculoskeletal system with special reference to osteochondrosis. Equine Vet J Suppl 31,112-119

Billinghurst R. C., Brama P. A. J., van Weeren P. R., Knowlton M. S. und Mcllwraith C. W. (2004): Evaluation of serum concentrations of biomarkers of skeletal metabolism and results of radiography as indicators of severity of osteochondrosis in foals. Am J Vet Res 65,143-150

Birkeland R. und Haakenstad L. H. (1968): Intracapsular bony fragments of the distal tibia of the horse, J Am Vet Med Assoc $152,1526-1529$ 
Brama P. A. J., Barneveld A. und van Weeren P. R. (2004): Functional adaptation of equine articular cartilage, Proc Am Assoc Equine Pract Focus on Joints Meet Louisville (KY), 145-156

Brama P. A. J., TeKoppele J. M., Bank R. A., Barneveld A. und van Weeren P. R. (2000): Functional adaptation of articular cartilage: the formation of regional biochemical characteristics up to age one year, Equine Vet J 32, 217-221

Brama P. A. J., TeKoppele J. M., Bank R. A., Barneveld A. und van Weeren P. R. (2002): Development of biochemical heterogeneity of articular cartilage: influences of age and exercise. Equine Vet $J$ 34, 265-269

Bridges C. H., Womack J. E., Harris E. D. und Scrutchfield W. L. (1984): Considerations of copper metabolism in osteochondrosis in suckling foals, J Am Vet Med Ass 185, 173-178

Carlson C. S., Cullins L. D. und Meuten J. D. (1995): Osteochondrosis of the articular-epiphyseal cartilage complex in young horses: evidence for a defect in cartilage canal blood supply, Vet Pathol 32, 641-647

Carlsten J., Sandgren B. und Dalín G. (1993): Development of osteochondrosis in the tarsocrural joint and osteochondral fragments in the fetlock joints of Standardbred trotters. I. A radiological survey, Equine Vet J Suppl 16, 42-47

Dabareiner R. M., Sullins K. E. und White II N. A. (1993): Progression of femoropatellar osteochondrosis in nine young horses. Clinical, radiographic and arthroscopic findings, Vet Surg 22, 515-523

Dik K. J., Enzerink E. E. und van Weeren P. R. (1999): Radiographic development of osteochondral abnormalities, in the hock and stifle of Dutch Warmblood foals, from age 1 to 11 months, Equine Vet J Suppl 31, 9-15

Denoix J. M. und Valette J. P. (2001): Pathologie ostéo-articulaire chez le jeune cheval (incidence, évaluation clinique, facteurs de risque et conséquences, Proc. Journée d'étude des Haras Nationaux 27, 101-113

Ekman S., Rodriguez Martinez H. und Plöen L. (1990): Morphology of normal and osteochondritic porcine articular-epiphyseal cartilage, Acta Anat 139, 239-253

Enzerink E., Dik K. J. und Knaap J. (2000): Radiographic development of lesions in hock and stifle in a group of Dutch Warmblood horses from 1-24 months of age, Proc Brit Equine Vet Assoc 39, 195

Glade M. J. (1986): The control of cartilage growth in osteochondrosis: a review, J Equine Vet Sci 6, 175-187

Glade M. J. (1987): The role of endocrine factors in equine developmental orthopedic disease, Proc Am Assoc Equine Pract 33, $171-189$
Glade M. J. und Belling T. H. (1984): Growth plate cartilage metabolism, morphology and biochemical composition in over- and underfed horses, Growth 48, 473-482

Helminen H. J., Hyttinen M. M., Lammi M. J., Arokoski J. P. A., Lapveteläinen T., Jurvelin J., Kiviranta I. und Tammi M. J. (2000): Regular joint loading in the youth assists in the establishment and strengthening of the collagen network of articular cartilage and contributes to the prevention of osteoarthrosis later in life; a hypothesis, J Bone Min Metab 18, 245-257

Henson F. M. D., Davies M. E. und Jeffcott L. B. (1997a): Equine dyschondroplasia (osteochondrosis) - histological findings and type VI collagen localization, Vet J 154, 53-62

Henson F. M. D., Schofield P. N. und Jeffcott L. B. (1997b): Expression of transforming growth factor- $B 1$ in normal and dyschondroplastic articular growth cartilage of the young horse, Equine Vet J $29,434-439$

Hoppe F. und Philipsson J. (1985): A genetic study of osteochondrosis dissecans in Swedish horses., Equine Practice 7, 7-15

Jeffcott L. B. (1991): Osteochondrosis in the horse - searching for the key to pathogenesis, Equine Vet J 23, 331-338

Jeffcott L. B. und Henson F. M. D. (1998): Studies on growth cartilage in the horse and their application to aetiopathogenesis of dyschondroplasia (osteochondrosis), Vet J 126,177-192

Knight D. A., Gabel A. A., Reed S. M., Embertson R. M., Tyznik W. J. und Bramlage L. R. (1985): Correlation of dietary mineral to incidence and severity of metabolic bone disease in Ohio and Kentucky. Proc Am Assoc Equine Pract 31, 445-460

König F. (1887): Über freie Körper in den Gelenken, Dtsch Z klin Chir 27, 90-109

Laverty S., O'Kouneff S., lonescu M., Reiner A., Pidoux I., Webber C., Rossier Y., Billinghurst R. C. und Poole A. R. (2002): Excessive degradation of type II collagen in articular cartilage in equine osteochondrosis, J Orthop Res 20, 1282-1289

Löhring K. und Distl O. (2004): Entwicklung eines genomweiten Markersets für die Aufdeckung von QTL beim Pferd. In: Proc. Göttinger Pferdetage '04, Göttingen, Institut für Tierzucht und Haustiergenetik Georg-August-Universität, 163-172

Maroudas A. (1980): Metabolism of cartilaginous tissues: A quantitative approach. In: Maroudas A., Holborrow E. J., editors: Studies in joint disease. vol 1, Tunbridge Wells, Pitman Medical, 59-86

Muir H. (1995): The chondrocyte, architect of cartilage, Bio Essays 17, 1039-1048

Nilsson F. (1947): Hästens goniter, Svensk Vetidn 52, 1-14

Olsson S. E. und Reiland S. (1978): The nature of osteochondrosis in animals. Acta Radiol Suppl 358, 299-306 
Paasch K. M. und Bramlage L. R. (2004): Influence of birth month on location of osteochondrosis dissecans, Proc Am Assoc Equine Pract Focus on Joints Meet Louisville (KY), 17-18

Philipsson J. (1996): Pathogenesis of osteochondrosis - genetic implications. In: Mcllwraith C. W., Trotter G. W., editors: Joint disease in the horse, Philadelphia, Saunders Company, 359-362

Reiland S. (1978): Morphology of osteochondrosis and sequelae in pigs, Acta Radiol Suppl 358, 45-90

Reiland S., Strömberg B., Olsson S. E., Dreimanis I. und Olsson I. G. (1978): Osteochondrosis in growing bulls. Pathology, frequency and severity on different feedings, Acta Radiol Suppl 358, 179-196

Rejnö S. und Strömberg B. (1978): Osteochondrosis in the horse II. Pathology. Acta Radiol Suppl 358, 153-178

Sandgren B., Dalin G. und Carlsten J. (1993): Osteochondrosis in the tarsocrural joint and osteochondral fragments in the fetlock joints in Standardbred trotters. I. Epidemiology, Equine Vet J Suppl $16,31-37$

Schougaard H., Falk Rønne J. und Philipsson J. (1990): A radiographic survey of tibiotarsal osteochondrosis in a selected population of trotting horses in Denmark and its possible genetic significance, Equine Vet J 22, 288-289

Semovolos S. A., Brower-Toland B. D., Bent S. J. und Nixon A. J. (2002): Parathyroid hormone-related peptide and Indian hedgehog expression patterns in naturally acquired equine osteochondrosis, J Orthop Res 20, 1290-1297

Semovolos S. A., Nixon A. J. und Strassheim M. L. (2004): Expression of bone morphogenic protein- 6 and -2 and a bone morphogenic protein antagonist in horses with naturally acquired osteochondrosis, Am J Vet Res 65, 110-115

Shingleton W. D., Mackie E. J., Cawston T. E. und Jeffcott L. B. (1997): Cartilage canals in equine articular / epiphyseal growth cartilage and a possible association with dyschondroplasia, Equine Vet J 29, 360-364

Strömberg B. (1979): A review of the salient features of osteochondrosis in the horse, Equine Vet J 11, 211-214

Strömberg B. und Rejnö S. (1978): Osteochondrosis in the horse I. A clinical and radiologic investigation of osteochondritis dissecans of the knee and hock joint, Acta Radiol Suppl 358, 139-152

Valentino L. W., Lillich J. D., Gaughan E. M., Biller D. R. und Raub R. $H$. (1999): Radiographic prevalence of osteochondrosis in yearling feral horses, Vet Comp Orthop Traumatol 12, 151-155

Van den Hoogen B. M., van de Lest C. H. A. und van Weeren P. R. (1999): Changes in proteoglycan metabolism in in osteochondrotic articular cartilage of growing foals, Equine Vet J Suppl 31, 38-44

Van de Lest C. H. A., Brama P. A. J., van El B., DeGroot J. und van Weeren P. R. (2004): Extracellular matrix changes in early osteochondrotic defects in foals: a key role for collagen? BBA Mol Basis Dis. 1690, 54-62
Van Weeren P. R. (2004): Osteochondrosis: developmental disorder or disorderly development? (OC seen in the general framework of articular development in young animals), Proc Ann Sci Meet Eur Coll Vet Surg 13, 164-175

Van Weeren P. R. und Barneveld A. (1999a): Study design to evaluate the influence of exercise on the development of the musculoskeletal system of foals up to age 11 months, Equine Vet J Suppl $31,4-8$

Van Weeren P. R. und Barneveld A.(1999b): The effect of exercise on the distribution and manifestation of osteochondrotic lesions in the Warmblood foal, Equine Vet J Suppl 31, 16-25

Van Weeren P. R. und Brama P. A. J. (2003): Equine joint disease in the light of new developments in articular cartilage research, Pferdeheilkunde 19, 336-344

Van Weeren P. R., Knaap J. und Firth E. C. (2003): Influence of liver copper status of mare and newborn foal on the development of osteochondrotic lesions, Equine Vet J 35, 67-71

Verzijl N., DeGroot J., Thorpe S. R., Bank R. A., Shaw N. J., Lyons T. J., Biilsma J. W. J., Lafeber F. P. J. G., Baynes J. W. und TeKoppele J. M. (2000): Effect of collagen turnover on the accumulation of advanced glycation end products, J Biol Chem 275, 39027 39031

Voûte L. C., Henson F. M. D., Platt D. und Jeffcott L. B. (1997):Lesions of the lateral trochlear ridge of the distal femur in ponies with histological features of equine dyschondroplasia, Proc Brit Equine Vet Assoc 36, 153-154

Wilke A. (2003): Der Einfluss von Aufzucht und Haltung auf Osteochondrose. Vet. Med. Diss. Hannover

Wolff J. (1892): Das Gesetz der Transformation der Knochen, Hirschwald, Berlin

Ytrehus B. (2004): Osteochondrosis. A morphological study of aetiology and pathogenesis. Vet. Med. Diss. Oslo

Ytrehus B., Carlson C. S., Lundeheim N., Mathisen L., Reinholt F. P., Teige J. und Ekman S. (2004): Vascularization and osteochondrosis of the epiphyseal growth cartilage of the distal femur in pigs development with age, growth rate, weight and joint shape, Bone $34,454-465$

P. René van Weeren DVM PhD Dipl ECVS,

Department of Equine Sciences,

Faculty of Veterinary Medicine,

Utrecht University,

Yalelaan 12,

3584 CM Utrecht,

The Netherlands

rvanweeren@vet.uu.nl

\section{If 1 ahnheilkunde \\ 23. -24. Juli 2005 \\ Humboldt-UniversitätBerlin \\ www.pferdeheilkunde.de}

